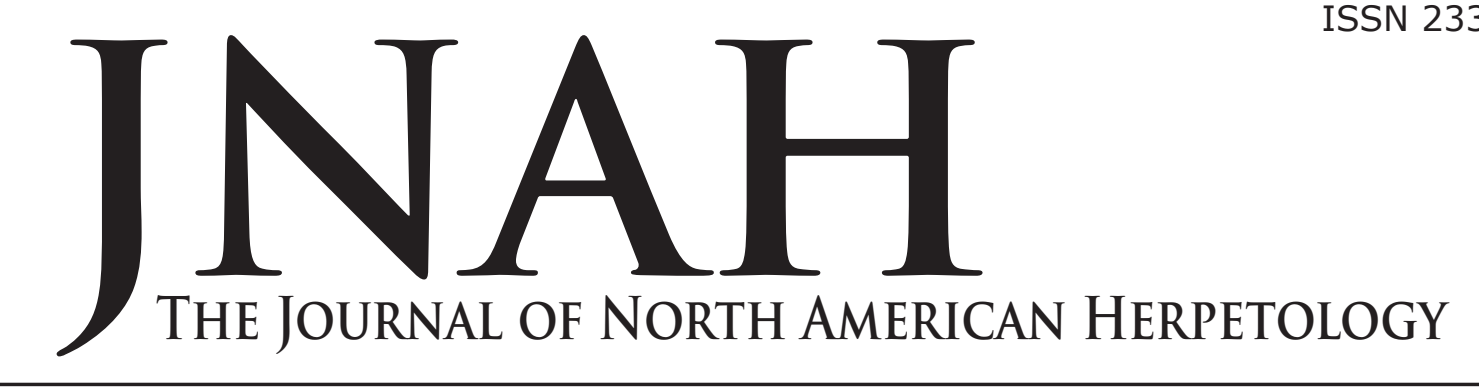

ISSN 2333-0694

Volume 2014(1): 28-39 31 January 2014

jnah.cnah.org

\title{
NATURAL HISTORY OF \\ DEKAY'S BROWNSNAKE, STORERIA DEKAYI (HOLBROOK, 1836), AT A SITE IN NORTHWESTERN PENNSYLVANIA
}

\author{
BRIAN S. GRAY \\ Natural History Museum at the Tom Ridge Environmental Center, 301 Peninsula Drive, Erie, Pennsylva- \\ nia 16505 - brachystoma@hotmail.com
}

'What was once a vacant lot where one could find snakes under sheets of rusty iron is now a parking lot or an apartment building.' - William S. Burroughs, 1987

\begin{abstract}
A population of Dekay's Brownsnake, Storeria dekayi was studied using mark-recapture techniques in Erie County, Pennsylvania, USA during the spring, summer and autumn of 2012. Morphometric data were similar to that reported for the species, with adult females averaging larger and more massive than adult males. However, sexual dimorphism in snout-vent length (SVL) and total length $(T L)$ was not significantly different $(P>0.05)$ in juveniles, although relative tail length $(\mathrm{tl} / \mathrm{TL})$ was dimorphic. Relative tail length in both juveniles and adults was greater in males ( $\mathrm{tl} / \mathrm{TL}=$ $0.22-0.27$ ) than females ( $\mathrm{tl} / \mathrm{TL}=0.18-0.23)$. Storeria dekayi were active from 21 March through 22 October, and displayed a bimodal activity pattern, with peaks in April and August. Using the Schnabel and the Schumacher-Eschmeyer methods, population size was estimated to be $122 \pm 19$ and $130 \pm$ 35 individuals, respectively. Density was estimated to be 244 and 260 snakes/ha, and biomass 1.60 and $1.71 \mathrm{~kg} / \mathrm{ha}$. Additional data regarding population structure, mortality, diet, reproduction, body temperature, movements and site fidelity are also presented.
\end{abstract}

\section{INTRODUCTION}

Habitat modification and loss, together with the impact of introduced predators and feral pets, remain the primary causes for snake population declines (McDiarmid et al. 2012). Dekay's Brownsnake, Storeria dekayi (Holbrook, 1836), is one of the few species of North American snakes that can thrive in urban environments (Hulse et al. 2001; Willson and Dorcas 2004). Klemens (1993) suggested that $S$. dekayi may even be capable of expanding its range as rural areas become increasingly urbanized. Despite this, it is not immune to the effects of habitat alteration and destruction. While it is uncertain if Burroughs (1987) was referring to the Dekay's Brownsnake in the above quote, the loss of habitat and disappearance of snakes described could certainly apply to this species. Murphy (2010) described the disappearance of $S$. dekayi and six other snake species from a site in northeastern Illinois, where over a period of twenty years the site was cleaned up, a wetland drained, and a housing development built. Ernst (2003) noted that residential development caused the extirpation of two populations of S. dekayi in Lancaster County, Pennsylvania. Loss of suitable habitat for S. dekayi in Erie County, Pennsylvania was described in Gray (2006; 2009).

Researchers have noted that basic life-history data are lacking for some common snake species (Willson and Dorcas 2004; Meshaka 2010), including S. dekayi (Ernst 2003; Gaul 2008). In Pennsylvania, the lack of information pertaining to the current status of most species, as well as lack of basic life history data, is recognized as challenges to conserving the commonwealth's herpetofauna (Hulse et al. 2001; Maret 2010). Such gaps in our knowledge of population biology can limit the ability to develop effective conservation and management strategies (Dorcas and Willson 2009). For example, thorough knowledge of a species' habitat use, population structure, and movement patterns are necessary for the establishment of adequate-sized reserves (Dodd 1987; Gregory et al. 1987; Shine and Bonnet 2009). Ernst (2003) provided a wealth of information regarding the ecology of 


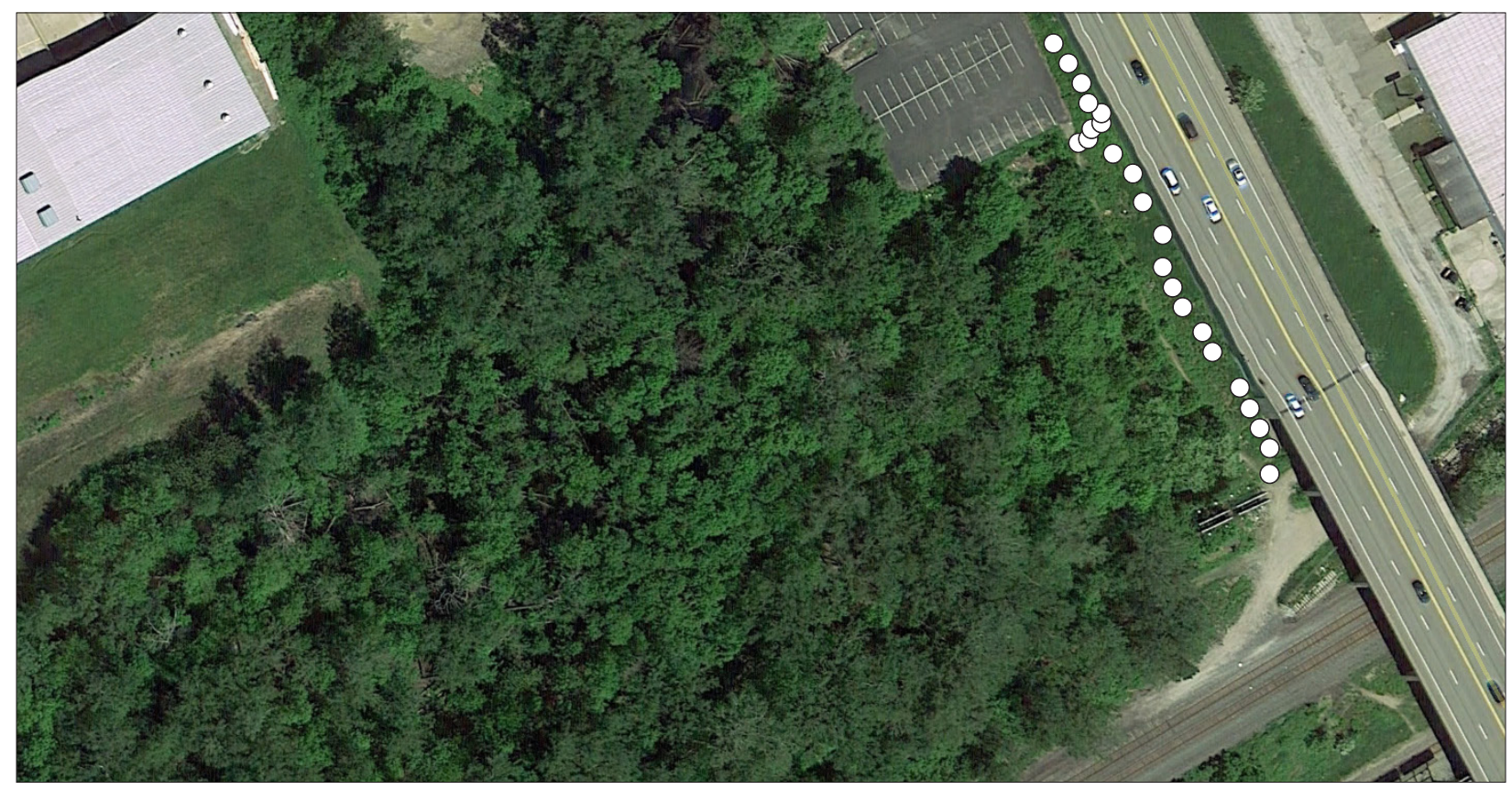

Figure 1. Map of the HWY 832 site in Millcreek Township, Erie County, Pennsylvania. Map is oriented with North at the top. The white dots are approximate locations of debris objects along the area of slope.

S. dekayi from southeastern Pennsylvania. In this paper, I report on the ecology of $S$. dekayi from northwestern Pennsylvania that further adds to our knowledge of this abundant, yet often overlooked serpent.

Study site - The study site is within the glaciated Central Lowland Province of northwest Pennsylvania and consists of approximately 0.5 ha of vegetated slope abutting the western side of the Highway (HWY) 832 Bridge in Millcreek Township, Erie County $\left(42.09385^{\circ} \mathrm{N}\right.$, $80.14170^{\circ} \mathrm{W}$; WGS84; $221 \mathrm{~m}$ elevation). The slope was dominated by Crown Vetch (Coronilla varia), Mugwort (Artemisia vulgaris), Goldenrod (Solidago sp.), and Late Flowering Thoroughwort (Eupatorium serotinum). Also present along the base of the slope were a few well-separated small trees and shrubs (Boxelder, Acer negundo; Red-osier Dogwood, Cornus sericea; Honeysuckle, Lonicera sp.; and Ash, Fraxinus sp.). To the west of the slope, the terrain is relatively flat and consists of ca. 3.25 ha of palustrine forest, with Eastern Cottonwood (Populus deltoides), Silver Maple (Acer saccharinum), Green Ash (Fraxinus pennsylvanica), and Pussy Willow (Salix discolor) dominating. The site, including the palustrine forest, is bounded to the north and south by residential and industrial development. Pre-existing debris at the site included pressed wood panels, boards, shingles, linoleum, and cardboard. The herpetofauna of adjacent property to the west of the site has been reported in Gray (2007; 2009; 2011).

\section{MATERIALS AND METHODS}

I visited the site 121 times (51.4 hrs. effort) from 21 March 2012 to 22 October 2012. Seventy-nine of the visits occurred between 0800 and $1130 \mathrm{~h}$ EST, with the remaining forty-two occurring between 1635 and $2000 \mathrm{~h}$ EST. It usually took less than $0.5 \mathrm{~h}$ to search all twenty debris objects along the western side of the HWY 832 Bridge. Sixteen (CB1-16) of the debris objects formed a 68.5 m north-south transect along the HWY 832 Bridge; the remaining four debris objects (PL1-4) ran perpendicular to the bridge along the southern edge of a park- ing lot, forming a $25 \mathrm{~m}$ west-east transect (Figure 1). Distance between debris objects averaged $7.5 \pm 3.1 \mathrm{~m}$ (range 1.0-20.9, $\mathrm{n}=19$ ).

Air temperature at the site was obtained with a Lascar Electronics temperature data logger (model EL-USB-1) with an accuracy of $\pm 1^{\circ} \mathrm{C}$ placed $1 \mathrm{~m}$ above ground in a shaded area. The temperature data logger was set to record a reading every $0.5 \mathrm{~h}$. Surface body temperature of snakes (BT) was taken with a hand-held infrared thermometer (Raytec MT-6) precise to $0.2^{\circ} \mathrm{C}$ (accuracy of \pm $1 \%$ between $10-30^{\circ} \mathrm{C}$ and $\pm 1.5 \%$ outside this range). The thermometer was held approximately $200 \mathrm{~mm}$ from the snake and in line with the snake's body axis (Hare et al. 2007). At a distance of $200 \mathrm{~mm}$, a circular area of approximately $20 \mathrm{~mm}$ in diameter is sampled. To lessen the likelihood of obtaining readings of both snake and substrate, only snakes that were coiled were utilized for temperature data. Snakes were hand captured,

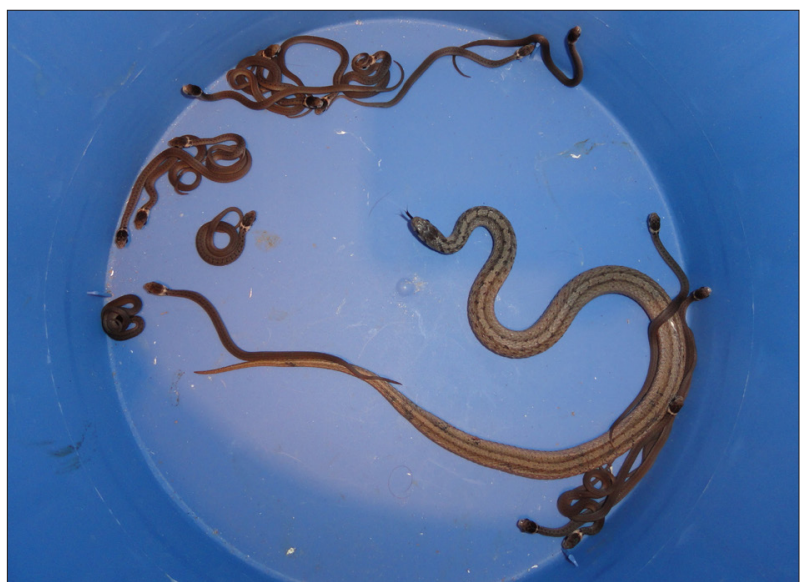

Figure 2. Female Storeria dekayi collected 20 July 2012 with neonates 24 July 2012 . Two stillborn young are not in the image. This litter $(n=20)$ represents the largest for an Erie County female $S$. dekayi. 
Table 1. A summary of the data and method used in the estimation of population size (N) of Storeria dekayi with the Schumacher-Eschmeyer method.

\begin{tabular}{|c|c|c|c|c|c|c|c|}
\hline Sample & $\begin{array}{c}\text { Number } \\
\text { Caught (C) }\end{array}$ & $\begin{array}{c}\text { Recaptures } \\
\text { (R) }\end{array}$ & $\begin{array}{l}\text { Number } \\
\text { Marked }\end{array}$ & $\begin{array}{c}\text { Marked (M) } \\
\text { at Large }\end{array}$ & $\mathrm{CXM}$ & $M \times R$ & $\mathrm{CxM}^{2}$ \\
\hline 1 & 5 & 0 & 5 & 0 & 0 & 0 & 0 \\
\hline 2 & 36 & 2 & 34 & 5 & 180 & 10 & 900 \\
\hline 3 & 21 & 8 & 13 & 39 & 819 & 312 & 31941 \\
\hline 4 & 13 & 9 & 4 & 52 & 676 & 468 & 35152 \\
\hline 5 & 13 & 9 & 4 & 56 & 728 & 504 & 40768 \\
\hline 6 & 9 & 3 & 6 & 60 & 540 & 180 & 32400 \\
\hline 7 & 7 & 3 & 4 & 66 & 462 & 198 & 30492 \\
\hline 8 & 10 & 3 & 7 & 70 & 700 & 210 & 49000 \\
\hline 9 & 6 & 3 & 3 & 77 & 462 & 231 & 35574 \\
\hline 10 & 8 & 3 & 5 & 80 & 640 & 240 & 51200 \\
\hline 11 & 1 & 0 & 1 & 85 & 85 & 0 & 7225 \\
\hline 12 & 6 & 4 & 2 & 86 & 516 & 344 & 44376 \\
\hline \multirow[t]{2}{*}{13} & 2 & 2 & 0 & 88 & 176 & 176 & 15488 \\
\hline & & $\begin{array}{r}\sum \mathrm{R}= \\
49\end{array}$ & & & $\begin{array}{r}\Sigma C M= \\
5984\end{array}$ & $\begin{array}{r}\sum M \times R= \\
2873\end{array}$ & $\begin{array}{l}\sum \mathrm{CxM}^{2}= \\
374516\end{array}$ \\
\hline
\end{tabular}

Schumacher-Eschmeyer method:

$\mathrm{N}=\Sigma \mathrm{CXM}^{2} / \Sigma \mathrm{MXR}=374516 / 2873=130.357$

sexed, and their snout-vent length (SVL) and tail length (tl) measured with a metric ruler to the nearest $\mathrm{mm}$. As in many natricine snakes, sex of mature $S$. dekayi was determined by examining the base of the tail. In males the hemipenes cause the sides of the base of the tail to bulge, whereas in females, the base of the tail is more tapered (Rossman et al. 1996). In neonates and young < $150 \mathrm{~mm}$ the hemipenes were manually everted in males by grasping the snake at mid-tail and rolling the thumb on the ventral surface towards the cloaca. Sex determination was further confirmed by examining relative tail length as per Hulse et al. (2001). Mass for each snake was obtained with a Pesola spring scale accurate to 0.1 g. In addition scale anomalies, such as cleft or fused scales, and whether or not the tail was complete were also noted. General descriptions of the pattern of dorsal spots and/or barring were recorded to aid in individual recognition. As per Hulse et al. (2001) males that were at least $175 \mathrm{~mm} \mathrm{SVL}$, and females that were at least $220 \mathrm{~mm}$ SVL were considered to be adults. Snakes were individually marked with a portable cautery unit (Winne et al. 2006) and released at the site of capture. Monthly growth rate was estimated by obtaining the difference in SVL between the initial and latest capture, dividing this by the number of days between the initial and latest capture dates, and then multiplying by 30.5 . With regards to estimating growth rates: Only snakes that were recaptured at least 30 days after their initial capture were used. Furthermore, only instances for which the increase in SVL between initial and latest capture was greater than $4 \%$ were considered.

Distances between debris objects were measured with a fiberglass tape measure to the nearest $0.1 \mathrm{~m}$. For all snakes the distance between successive recapture and the last capture (if at two different debris objects) was determined to give a minimum distance traveled (Freedman and Catling 1979). For snakes with multiple recaptures, the minimum distances traveled were summed to give a total distance traveled.

Student's t-tests (two tailed, $a=0.05$ ) were used to compare SVL, total length ( $T L$ ), relative tail length (tl/ $\mathrm{TL})$, mass, and body temperatures between sexes and between and among juveniles and adults. Prior to performing t-tests, an F-test was used to determine whether variances were homogenous. In the event variances were heterogeneous, a t-test assuming unequal variances was employed (Runyon et al. 1996). Chi-square tests were used to determine if sex ratios and juvenile to adult ratios were significantly different from a $1: 1$ ratio $(a=$ $0.05)$. Population size (N) was estimated using both the Schumacher-Eschmeyer (Ricker 1975; Schneider 1998) and the Schnabel (Seber 1973) mark-recapture methods. For each population estimate each sample consisted of a weekly sampling period. DeLury (1958 cited in Caughley 1977) noted that the Schumacher-Eschmeyer method is often more accurate than the Schnabel method in that it depends less on random mixing of marked and unmarked individuals. Standard errors and 95\% confidence intervals were calculated for each estimate. In order to reduce the likelihood of violating the assumption of no births, only data from prior to 14 July were used in calculating population size. This date corresponded with the first post-parturition female, and the first neonates of the year being observed. From the population estimates,

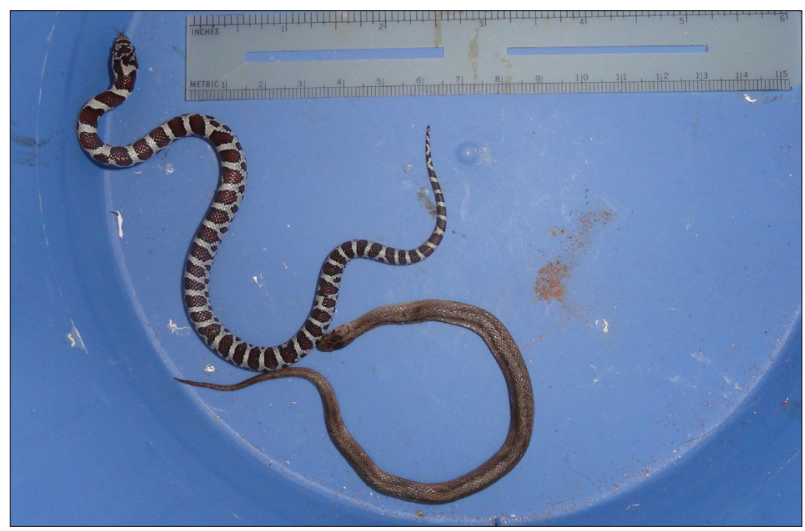

Figure 3. Juvenile male Milksnake, Lampropeltis triangulum (217mm SVL) with disgorged male juvenile Storeria dekayi (144mm SVL) 7 September 2012. The S. dekayi was disgorged tail first. 
Table 2. A summary of prey items disgorged by Storeria dekayi $(n=9)$ from the HWY 832 site in Erie County, Pennsylvania.

\begin{tabular}{|c|c|c|c|c|c|c|c|}
\hline DATE & SNAKE & SEX & $\mathrm{SVL}(\mathrm{mm})$ & $\mathrm{TL}(\mathrm{mm})$ & $\begin{array}{l}\text { SNAKE } \\
\text { MASS }(g)\end{array}$ & PREY ITEMS & $\begin{array}{l}\text { PREY } \\
(g)\end{array}$ \\
\hline 31-May-12 & 1 & $\mathrm{~F}$ & 225 & 282 & 7.5 & Lumbricus rubellus $(n=1)$ & 0.3 \\
\hline 18-Aug-12 & 2 & M & 114 & 151 & 1.5 & Deroceras sp. $(n=1)$ & $<0.1$ \\
\hline 18-Aug-12 & 3 & $\mathrm{~F}$ & 148 & 184 & 2.5 & earthworm $(n=1)$ & $\mathrm{n} / \mathrm{a}$ \\
\hline 20-Aug-12 & 4 & $\mathrm{~F}$ & 139 & 175 & 2.3 & $\begin{array}{l}\text { Arion sp. }(n=2) ; \text { Deroceras sp. }(n=1) ; \\
\text { unidentified slug }(n=1)\end{array}$ & 0.1 \\
\hline 24-Aug-12 & 5 & $\mathrm{~F}$ & 145 & 183 & 2.5 & $\begin{array}{l}\text { Arion hortensis complex }(\mathrm{n}=1) \\
\text { Arion } \mathrm{sp} .(\mathrm{n}=1) \\
\text { Deroceras } \mathrm{sp} .(\mathrm{n}=2) \\
\text { unidentified slug }(\mathrm{n}=1) \\
\text { millipedes }(\mathrm{n}=2)\end{array}$ & 0.12 \\
\hline 1-Sep-12 & 6 & $\mathrm{~F}$ & 155 & 197 & 3.25 & D. reticulatum $(\mathrm{n}=1)$ & 0.1 \\
\hline 8-Sep-12 & 7 & M & 166 & 206 & 4 & L. rubellus $(\mathrm{n}=1)$ & 0.75 \\
\hline 16-Sep-12 & 8 & $\mathrm{~F}$ & 156 & 201 & 3.25 & D. reticulatum $(\mathrm{n}=3)$ & 0.1 \\
\hline 19-Sep-12 & 9 & $\mathrm{~F}$ & 142 & 180 & 2.25 & Arion sp. $(\mathrm{n}=1)$ & $<0.1$ \\
\hline
\end{tabular}

density was estimated by dividing the estimated population size by the area of habitat. Biomass was estimated by multiplying the average mass of snakes by $\mathrm{N}$ then dividing by the area of the site.

\section{RESULTS}

One hundred sixty-six S. dekayi (46 juvenile males, 50 juvenile females, 45 adult males, and 25 adult females) were captured and utilized in the analysis of morphometrics and sex ratios.

Morphometrics of juveniles - Snout-vent length (SVL) did not differ $(t=-1.97, d f=94, P=0.052)$ between Juvenile males (mean $142 \pm 6 \mathrm{~mm}$, range $72-173, \mathrm{n}=$ 46) and juvenile females (mean $151 \pm 7 \mathrm{~mm}$, range 117$205, n=50)$. Total length ( $T L)$ did not differ $(t=-0.61$, $\mathrm{df}=91, \mathrm{P}=0.55$ ) between juvenile males (mean 187 $\pm 8 \mathrm{~mm}$, range $95-232, \mathrm{n}=44$ ) and juvenile females (mean $191 \pm 8 \mathrm{~mm}$, range 149-260, $\mathrm{n}=49$ ). Relative tail length $(\mathrm{tl} / \mathrm{TL})$ differed $(\mathrm{t}=14.46, \mathrm{df}=91, \mathrm{P}=<0.001)$ between juvenile males (mean $0.240 \pm 0.003$, range $0.221-0.270, \mathrm{n}=44)$ and juvenile females (0.210 \pm 0.003 , range $0.180-0.231, \mathrm{n}=49$ ), with juvenile males averaging greater $\mathrm{tl} / \mathrm{TL}$. Mass did not differ $(\mathrm{t}=-1.58, \mathrm{df}$ $=79, \mathrm{P}=0.12$ ) between juvenile males (mean $2.4 \pm 0.2$ $\mathrm{g}$, range $0.37-4.0, \mathrm{n}=46$ ) and juvenile females (mean $2.7 \pm 0.3 \mathrm{~g}$, range $1.25-5.5, \mathrm{n}=45$ ).

Morphometrics of adults - Snout-vent length differed ( $\mathrm{t}=-10.00, \mathrm{df}=68, \mathrm{P}=<0.001$ ) between adult males (mean $216 \pm 6 \mathrm{~mm}$, range 175-267, $\mathrm{n}=45$ ) and adult females (mean $268 \pm 9 \mathrm{~mm}$, range $225-308, \mathrm{n}=25$ ), with adult females averaging larger SVLs. Total length differed ( $\mathrm{t}=-7.26, \mathrm{df}=64, \mathrm{P}=<0.001$ ) between adult males (mean $285 \pm 8 \mathrm{~mm}$, range 228-351, $\mathrm{n}=43$ ) and adult females (mean $333 \pm 11 \mathrm{~mm}$, range 282-378, $\mathrm{n}=$ 23) with adult females averaging larger TLs. Relative tail length differed $(\mathrm{t}=20.80, \mathrm{df}=64, \mathrm{P}=<0.001)$ between adult males (mean $0.240 \pm 0.002$, range 0.231-0.260, $\mathrm{n}=43$ ) and adult females (mean $0.201 \pm 0.002$, range $0.180-0.220, n=23$ ), with adult males averaging greater $\mathrm{tl} / \mathrm{TL}$. Mass differed $(\mathrm{t}=-7.10, \mathrm{df}=27, \mathrm{P}=<0.001)$ between adult males (mean $6.2 \pm 0.4 \mathrm{~g}$, range 3.2-12.0, $\mathrm{n}=45$ ) and adult females (mean $12.9 \pm 1.9 \mathrm{~g}$, range 7.0-23.8, $\mathrm{n}=25$ ), with adult females averaging greater mass.

Juveniles growth - Growth rate of juvenile male $S$. dekayi (initial SVL $135-173 \mathrm{~mm}$ ) recaptured 47 to 133 days after initial capture averaged $16.2 \pm 8.7 \mathrm{~mm} / \mathrm{month}$ (range $9.4-26.6, n=5$ ). Growth rate of juvenile female
S. dekayi (initial SVL 131-172 $\mathrm{mm}$ ) recaptured 33 to 68 days after initial capture averaged $25.2 \pm 8.6 \mathrm{~mm} / \mathrm{month}$ (range 14.3-38.1, $\mathrm{n}=7$ ).

Adult growth - Growth rate of adult male S. dekayi (initial SVL $180-227 \mathrm{~mm}$ ) recaptured 46 to 152 days after initial capture averaged $8.8 \pm 12.6 \mathrm{~mm} / \mathrm{month}$ (range $3.2-20.5, n=4)$. An adult female $S$. dekayi initially captured with a SVL of $269 \mathrm{~mm}$ was recaptured 112 days later with a $280 \mathrm{~mm} \mathrm{SVL}$, an increase of approximately $3.0 \mathrm{~mm} / \mathrm{month}$.

Sex ratios and juvenile to adult ratio - Total sex ratio of juvenile males $(n=46)$ to juvenile females $(n=50)$ $(1: 1.09)$ did not differ significantly from $1: 1\left(X^{2}=0.17\right.$, $\mathrm{df}=1, P>0.05)$. The total sex ratio of adult males ( $\mathrm{n}$ $=45)$ to adult females $(n=25)(1: 0.56)$ was significantly different from $1: 1\left(X^{2}=5.71, d f=1, P<0.05\right)$. However, apparent differences in adult sex ratios were evident between seasons, with males being biased in spring (1:0.45) and summer (1:0.47), and females more prevalent in autumn $(1: 1.17)$. The total ratio of juveniles $(n=96)$ to adults $(n=70)(1: 0.73)$ was significantly different from $1: 1(x 2=4.07, d f=1, P<0.05)$. The adult to juvenile ratios also differed between seasons, with adults biased in spring and summer, 1:0.73 and 1:0.59, respectively. During autumn, however, juveniles were more prevalent with an adult to juvenile ratio of $1: 3.92$.

Population size and density - A total of 88 S. dekayi (57 males and 31 females) were utilized in the estimation of population size. Using the Schumacher-Eschmeyer method (Table 1.), population size was estimated as 130 individuals ( $95 \% \mathrm{CI}=95-165, \mathrm{SE}=16.2)$, resulting in a density of $260 \mathrm{~S}$. dekayi/ha (95\% CI $190-330$ / ha), and a biomass density of $1.71 \mathrm{~kg} / \mathrm{ha}$ (95\% CI $1.25-$

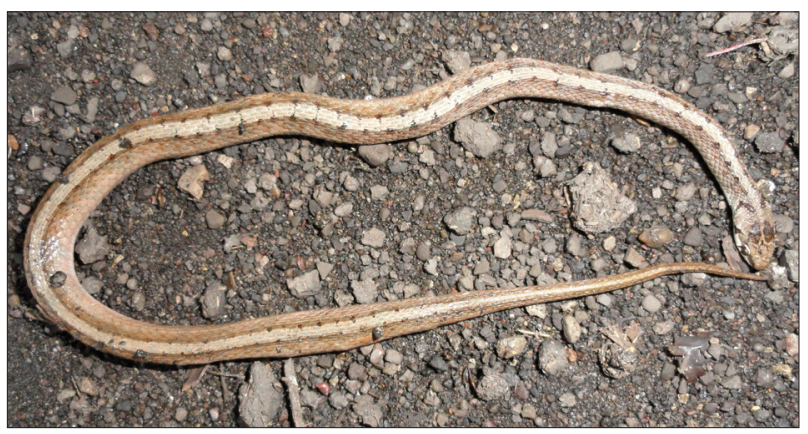

Figure 4. Female Storeria dekayi (237mm SVL) found dead on road (DOR) 28 July 2012. 
Table 3. Summary of surface body temperatures (BT) of Storeria dekayi and air temperature (AT) at the HWY 832 site in Erie County, Pennsylvania.

\begin{tabular}{|c|c|c|c|}
\hline Month & $\begin{array}{c}\text { Male BTs }{ }^{\circ} \mathrm{C} \\
\text { Average range }(n)\end{array}$ & $\begin{array}{c}\text { Female BTs }{ }^{\circ} \mathrm{C} \\
\text { Average range }(n)\end{array}$ & $\begin{array}{c}\text { Air Temp. }{ }^{\circ} \mathrm{C} \\
\text { Average range }(n)\end{array}$ \\
\hline April & $\begin{array}{c}2.2 \\
-0.2-5.6(6)\end{array}$ & $\begin{array}{c}3.1 \\
0.6-5.6(2)\end{array}$ & $\begin{array}{c}12.1 \\
3.9-21.7(15)\end{array}$ \\
\hline May & $\begin{array}{c}16.6 \\
9.8-26.2(29)\end{array}$ & $\begin{array}{c}16.2 \\
8.8-24.6(10)\end{array}$ & $\begin{array}{c}18.1 \\
10.1-26.0(19)\end{array}$ \\
\hline June & $\begin{array}{c}24.5 \\
14.2-30.6(15)\end{array}$ & $\begin{array}{c}21.7 \\
13.4-27.4(11)\end{array}$ & $\begin{array}{c}22.1 \\
11.0-29.0(25)\end{array}$ \\
\hline July & $\begin{array}{c}27.2 \\
24.0-30.2(10)\end{array}$ & $\begin{array}{c}25.6 \\
22.2-28.8(10)\end{array}$ & $\begin{array}{c}25.1 \\
17.0-29.0(21)\end{array}$ \\
\hline August & $\begin{array}{c}22.3 \\
17.4-28.8(32)\end{array}$ & $\begin{array}{c}23.6 \\
17.8-29.8(38)\end{array}$ & $\begin{array}{c}22.3 \\
18.0-27.0(23)\end{array}$ \\
\hline September & $\begin{array}{c}15.9 \\
9.6-26.4(15)\end{array}$ & $\begin{array}{c}16.7 \\
8.8-25.8(28)\end{array}$ & $\begin{array}{c}18.9 \\
12.0-26.0(12)\end{array}$ \\
\hline October & $\begin{array}{c}9.2 \\
7.4-11.0(2)\end{array}$ & $\begin{array}{c}7.5 \\
2.4-11.4(11)\end{array}$ & $\begin{array}{c}8 \\
4.0-10.0(6)\end{array}$ \\
\hline
\end{tabular}

$2.17 \mathrm{~kg} / \mathrm{ha})$. Population size as estimated by the Schnabel method was 122 individuals (95\% CI $=103-142$, SE = 9.9), resulting in a density of 244 S. dekayi/ha ( $95 \%$ $\mathrm{CI}=206-284 / \mathrm{ha})$, and a biomass density of $1.60 \mathrm{~kg} / \mathrm{ha}$ $(95 \% \mathrm{CI}=1.35-1.86 \mathrm{~kg} / \mathrm{ha})$.

Reproduction - Ten of 19 (53\%) adult female S. dekayi (225-308 mm SVL) found before 1 August 2012 were gravid. The first post-parturition female was observed on 14 July 2012, while the first neonates were found 15 July. A gravid female ( $273 \mathrm{~mm} \mathrm{SVL}, 14.75 \mathrm{~g}$ ) collected 20 July produced a litter of 20 young on 24 July (Figure 2 ). The litter consisted of 11 males (63-76 mm SVL) and 9 females (70-77 mm SVL); total mass of the litter was 6.5 g. Two of the males were stillborn. Relative clutch mass (RCM) was 0.441 .

Mortality and injuries - A total of 6 deceased S. dekayi were observed at the HWY 832 site with 3 being found crushed under debris, 2 being predated by juvenile Milksnakes, Lampropeltis triangulum (Figure 3), and 1 being predated by an unknown predator. Mortalities represented $3.6 \%$ of all S. dekayi found at the site. An additional $5 \mathrm{~S}$. dekayi were found DOR on nearby roads and trails (Figure 4). Stubbed tails were found in 4 males (2 juveniles and 2 adults), and 3 females ( 1 juvenile and 2 adults). A juvenile female ( $187 \mathrm{~mm} \mathrm{SVL})$ had a healed in-

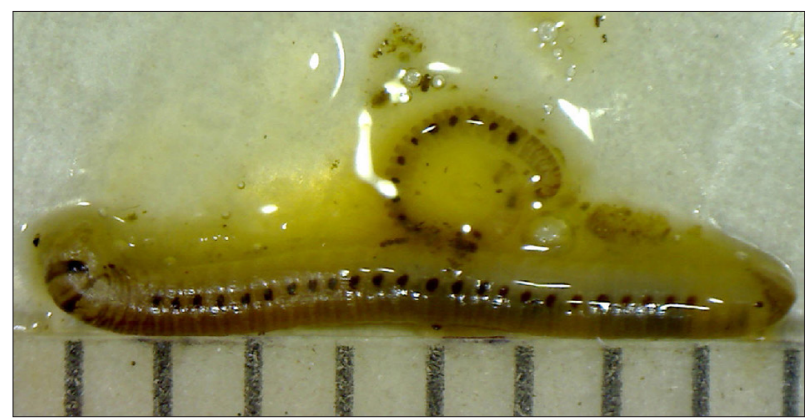

Figure 5. Millipedes of the order Julida disgorged by a Storeria dekayi (145mm SVL) on 24 August 2012. The snake had also consumed five slugs. The scale at the bottom of the image is in $1 \mathrm{~mm}$ increments.

jury involving a ventral scale and 5 scales in dorsal scale rows (DSR) $1-3$ on the right side, just beyond midbody.

Prey - Nine S. dekayi (2 males and 7 females) disgorged prey while being processed. Slugs were consumed by 6 of the snakes, while the other 3 had consumed earthworms (Table 2). In one instance, a juvenile female $S$. dekayi disgorged 2 millipedes (Figure 5) in addition to 5 slugs (Gray 2013a). Slugs of the genus Deroceras were consumed by 5 snakes, while Arion sp. was consumed by 4 snakes; $2 \mathrm{~S}$. dekayi had consumed both Arion and Deroceras slugs. Of the 3 S. dekayi that had consumed earthworms, 2 disgorged Lumbricus rubellus while the third disgorged an unidentified earthworm. Five S. dekayi captured 21 March 2012, defecated upon being handled, evidence that they had been successfully foraging. Snakes continued to feed into October, as evidenced by a juvenile female $S$. dekayi captured 22 October 2012, that defecated while being processed.

Table 4. Comparison of seasonal activity of male and female Storeria dekayi from the HWY 832 site in Erie County, Pennsylvania. Statistically significant differences are noted with an asterisk. n. s. = not statistically significant. Degrees of freedom (df) $=1$.

\begin{tabular}{|c|c|c|c|c|}
\hline \multicolumn{5}{|c|}{ Number of observations } \\
\hline Month & Males & Females & $x^{2}$ & $\mathrm{P}$ \\
\hline March & 3 & 4 & 0.14 & n.s. \\
\hline April & 54 & 17 & 19.28 & $<0.05^{*}$ \\
\hline May & 33 & 16 & 5.89 & $<0.05^{*}$ \\
\hline June & 15 & 11 & 0.62 & n.s. \\
\hline July & 11 & 11 & 0 & n.s. \\
\hline August & 33 & 40 & 0.67 & n.s. \\
\hline September & 18 & 28 & 2.17 & n.s. \\
\hline October & 3 & 11 & 4.57 & $<0.05^{*}$ \\
\hline
\end{tabular}


Table 5. Comparison of snout-vent (SVL) of Storeria dekayi from select regions of the eastern United States, including the HWY 832 site in Erie County, Pennsylvania.

\begin{tabular}{|c|c|c|c|c|c|}
\hline Source & Locality & $\begin{array}{c}\text { Male } \\
\text { Avg. SVL }\end{array}$ & $\begin{array}{c}\text { Female } \\
\text { Avg. SVL }\end{array}$ & $\begin{array}{l}\text { Male } \\
\text { tl/TL }\end{array}$ & $\begin{array}{l}\text { Female } \\
\text { tl/TL }\end{array}$ \\
\hline This study & nw PA & $\begin{array}{c}216.5(n=45) \\
\text { (range 175-267) }\end{array}$ & $\begin{array}{c}268(n=25) \\
\text { (range } 225-308)\end{array}$ & $\begin{array}{c}0.24(\mathrm{n}=43) \\
\text { (range } 0.23-0.26)\end{array}$ & $\begin{array}{c}0.2(n=23) \\
\text { (range } 0.18-0.22)\end{array}$ \\
\hline Hulse et al. 2001 & PA & $\begin{array}{c}210.7(n=53) \\
\text { (range } 175-255)\end{array}$ & $\begin{array}{c}254(n=68) \\
\text { (range } 222-303)\end{array}$ & $\begin{array}{c}0.24(n=49) \\
\text { (range } 0.22-0.26)\end{array}$ & $\begin{array}{c}0.19(n=64) \\
\text { (range } 0.18-0.22)\end{array}$ \\
\hline Klemens 1993 & $\mathrm{CT}$ & $\begin{array}{c}229.9(n=14) \\
\text { (range } 210-250)\end{array}$ & $\begin{array}{c}263.5(n=21) \\
\text { (range 192-312) }\end{array}$ & $\begin{array}{c}0.24(\mathrm{n}=14) \\
\text { na }\end{array}$ & $\begin{array}{c}0.19(\mathrm{n}=21) \\
\text { na }\end{array}$ \\
\hline Minton 2001 & IN & $\begin{array}{c}220.5(n=23) \\
\text { (range } 170-252)\end{array}$ & $\begin{array}{c}266.3(n=21) \\
\text { (range } 214-319)\end{array}$ & $\begin{array}{l}\text { na } \\
\text { na }\end{array}$ & $\begin{array}{l}\text { na } \\
\text { na }\end{array}$ \\
\hline Mitchell 1994 & VA & $\begin{array}{c}199.6(n=46) \\
\text { (range } 150-300)\end{array}$ & $\begin{array}{c}232.3(n=64) \\
\text { (range 175-296) }\end{array}$ & $\begin{array}{c}0.24(n=56) \\
\text { (range } 0.19-0.30)\end{array}$ & $\begin{array}{c}0.2(n=76) \\
\text { (range } 0.15-0.25)\end{array}$ \\
\hline Willson and Dorcas & NC & $\begin{array}{c}225.7(n=6) \\
\text { (range } 157-274)\end{array}$ & $\begin{array}{c}245.1(n=9) \\
\text { (range 186-288) }\end{array}$ & $\begin{array}{c}0.23(n=6) \\
\text { (range } 0.21-0.24)\end{array}$ & $\begin{array}{c}0.18(\mathrm{n}=9) \\
\text { (range } 0.10-0.22)\end{array}$ \\
\hline
\end{tabular}

Temperature - Body temperatures (BTs) were obtained during 219 captures of $S$. dekayi between 29 April and 20 October 2012. BTs did not differ $(t=0.10, \mathrm{df}=217, \mathrm{P}=$ 0.921 ) between males (mean $19.3 \pm 1.3^{\circ} \mathrm{C}$, range -0.2 $30.6, \mathrm{n}=109$ ) and females (mean $19.2 \pm 1.3^{\circ} \mathrm{C}$, range $0.6-29.8, \mathrm{n}=110$ ). BTs did not differ significantly ( $\mathrm{t}=$ $-0.75, \mathrm{df}=342, \mathrm{P}=0.453$ ) from air temperature, which averaged $19.3^{\circ} \mathrm{C}$ (Table 3 ).

Movements and site fidelity - Minimum distance traveled did not differ ( $t=-0.58, \mathrm{df}=62, \mathrm{P}=0.563$ ) between males (mean $31.3 \pm 7.8 \mathrm{~m}$, range $2.4-87.4, \mathrm{n}=$ 37 ) and females (mean $34.6 \pm 8.8 \mathrm{~m}$, range 2.9-75.0, $\mathrm{n}$ $=27)$. Thirty $(80.5 \%)$ of the movements by males, and twenty-one (76.9\%) movements by females were less than $50 \mathrm{~m}$. The total distance traveled did not differ $(\mathrm{t}=$ -0.13, df $=39, \mathrm{P}=0.898$ ) between males (mean 50.3 $\pm 15.0 \mathrm{~m}$, range $4-127.7, \mathrm{n}=23$ ) and females (mean $52.0 \pm 23.7 \mathrm{~m}$, range $2.9-164.3, \mathrm{n}=18)$. A male (161 $\mathrm{mm}$ SVL) was captured 5 times over a period of 57 days and traveled $127.7 \mathrm{~m}$; while a female (260 mm SVL) was captured 5 times over a period of 33 days and traveled $164.3 \mathrm{~m}$.

Site fidelity was observed in 23 males and 12 females. There were 32 instances involving a single debris station utilized by a snake 2-5 times, and 4 instances of 3 debris objects being utilized by a snake 2-6 times each. A female S. dekayi (161 mm SVL), over a period of 59 days (35 site visits) used 1 debris station twice and a second station 6 times. Three $S$. dekayi ( 2 males and 1 female) utilized a single debris object for 2-4 consecutive days for ecdysis. Days between observations of a $S$. dekayi under the same debris station averaged $14 \pm 7$ days (range $1-93, n=34$ ) in males and $9 \pm 4$ days (range $2-42, n=$ 31 ) in females.

Seasonal activity - Storeria dekayi displayed a bimodal activity pattern, with a peak of observations occurring in April, decreasing through May, June, and July, followed by a second peak in August, and another decrease in September and October (Figure 6). The bimodal activity pattern was similar between sexes, although the peak in April was more pronounced in males, while the August peak was more pronounced in females. April and May had significantly more captures of male than female $S$. dekayi (April: $\mathrm{X} 2=19.28, \mathrm{df}=1, \mathrm{P}<0.05$; May: $\mathrm{X}^{2}=$ 5.89 , df $=1, \mathrm{P}<0.05)$. Whereas October had significant- ly more captures of females than males $\left(X^{2}=4.57, \mathrm{df}=\right.$ $1, P<0.05$ ) (Table 4). The earliest and latest dates of observation were 21 March and 22 October.

\section{DISCUSSION}

Morphometrics - Sizes (SVL and TL) of adult male and female S. dekayi at the HWY 832 site were similar to those reported by other authors (Klemens 1993; Mitchell 1994; Hulse et al. 2001; Minton 2001; Willson and Dorcas 2004), with females averaging larger than males (Table 5). Sexual dimorphism in SVL and TL was not apparent in juveniles, although relative tail length was dimorphic. This is likely an artifact of sampling. The juvenile category was composed of several age groups, such as young of the year through second year young. Size dimorphism was apparent in a litter from the site, with female neonates being slightly larger than males (see above). Such sexual dimorphism in body size may be the result of elevated levels of testosterone in males (Shine and Crews 1988; King 1997). Adult females have relatively larger bodies and shorter tails to maximize space for embryo development (McDiarmid 2012). Larger size in females has also been suggested to be advantageous, as larger females are typically more fecund (Shine 1993). Mass was also similar to reports in the literature, with adult females averaging greater mass than adult males (Hulse et al. 2001, Willson and Dorcas 2004).

Growth - Growth may be influenced by numerous factors, including genetics, environmental temperatures, food availability, and the health of the individual (Vitt and Caldwell 2009). In general, growth is more rapid in juvenile snakes than in mature individuals. Growth data for

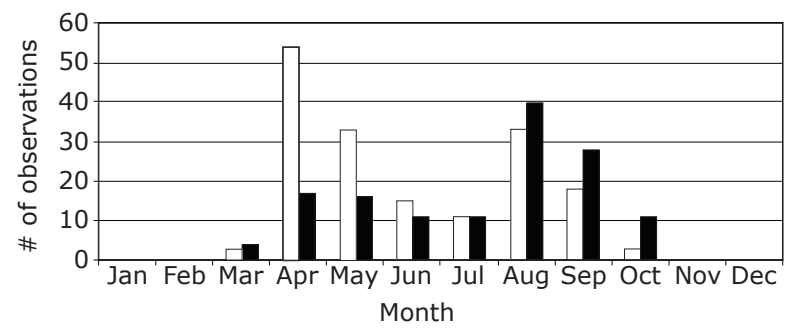

Figure 6. Seasonal activity of male (white) and female (black) Storeria dekayi along the HWY 832 Bridge in Erie County, Pennsylvania. 
Table 6. Relative abundance of Storeria dekayi, Thamnophis sirtalis, and Lampropeltis triangulum from the HWY 832 site in Erie County, Pennsylvania. Number of individuals observed during each period and percent (\%) of period totals is listed.

\begin{tabular}{lccc}
\hline & 21 March - & 16 June - & 16 August - \\
Species & 15 June & 15 August & 22 October \\
\hline \hline
\end{tabular}

Storeria dekayi

139
$(82.7 \%)$

\author{
63
}

$(24.8 \%)$

106

$(80.3 \%)$

Thamnophis sirtalis

$$
22
$$

$(13.1 \%)$

$$
182
$$

Lampropeltis triangulum

$$
\stackrel{9}{(3.5 \%)}
$$

Period totals

168
$(100 \%)$

254
$(100 \%)$
$(100 \%)$

S. dekayi is sparse (Ernst and Ernst 2003). Ernst (2003) observed average increases in SVL of $14.1 \%$ for neonates recaptured about a month later, and increases of $10.9 \%$ and $8.2 \%$ SVL for one and two year olds, respectively. At the HWY 832 site, estimated average monthly increases in SVL were $14.1 \%$ for juveniles, and $4.4 \%$ for adults.

Sex ratios and juvenile to adult ratio - Sex ratios for neonate and adult $S$. dekayi are often female-biased (Clausen 1936; Freedman and Catling 1978; Ernst and Barbour 1989; Ernst and Ernst 2003). In the single litter from the HWY 832 site, males $(n=11)$ outnumbered females $(n=9)$, and the sex ratio of juveniles was approximately equal; in adults, the total sex ratio was male-biased (1:0.56). As noted by Parker and Plummer (1987), differences in behavior between sexes can confound efforts to determine the actual sex ratios of snake populations. For instance, female $S$. dekayi may become more sedentary, more reclusive, or feed less frequently when gravid (Parker and Plummer 1987). Also, a gravid female snake's tendency to thermoregulate under cover objects could also potentially make gravid females more susceptible to predation risks (Meshaka et al. 2008), resulting in greater mortality of females. Conversely, Hecnar and Hecnar (2011) suggested that the choice of large, moderately decayed woody debris by female $S$. dekayi potentially lowered predation risks. Increased activity by non-gravid or postpartum female $S$. dekayi, such as moving about in the open or attempting to cross roads, could also increase the risk of mortality. Between 14 July and 28 September 2012, five female S. dekayi were found dead on nearby roads and trails within $1.6 \mathrm{~km}$ west of the HWY 832 Bridge. It has been reported that male S. dekayi are more active than females in the fall season (Hulse et al. 2001; Meshaka et al. 2008), however, the converse was true at the HWY 832 site. During August through October, observations of female S. dekayi outnumbered those of males $1.2-3.7$ times. Conant (1938) stated that in Ohio, males outnumbered females in the spring, but in the summer, when females were gravid, males were less numerous.

Population size and density - Populations of S. dekayi can be large with high densities (Ernst and Ernst 2003), especially when there is an abundance of slugs and earthworms, and an absence of Milksnakes (Lazell 1976). Ernst (2003) estimated two southeastern Pennsylvania
S. dekayi populations to contain 704 (range 488-920) and 152 (56-248) individuals, with resulting population densities of $300 /$ ha and 66/ha, respectively. Pisani (2009) estimated a Kansas population of S. dekayi to be 160 snakes with a density of 32/ha. Population sizes reported by Freedman and Catling (1978) in southwestern Ontario, Canada ranged from 471 to 610 and averaged 545 snakes with a density of approximately 70/ha. The population size estimates of 122 and 160 snakes at the HWY 832 site was similar to the estimates obtained by Ernst (2003) in southeast Pennsylvania, and Pisani (2009) in Kansas. Due to the relatively high numbers of recaptures at the HWY 832 site, both standard errors and confidence intervals were small. The estimated density of S. dekayi at the HWY 832 site (244-260/ha) is similar to Ernst's estimate for the larger of his southeastern Pennsylvania populations noted above. Biomass density at two southeastern Pennsylvania sites was estimated to be $0.987 \mathrm{~kg} / \mathrm{ha}$ and $0.404 \mathrm{~kg} / \mathrm{ha}$ (Ernst 2003). Total density estimates at the HWY 832 site $(0.788 \mathrm{~kg}$ and $0.854 \mathrm{~kg})$ was within the estimates of Ernst (2003) for two southeastern Pennsylvania sites $(0.605 \mathrm{~kg}$ and $1.97 \mathrm{~kg})$. The biomass density of the HWY 832 site was slightly larger $(1.71 \mathrm{~kg} / \mathrm{ha})$ than both of Ernst's estimates, partly due to the very small size (i.e. 0.5 ha) of the HWY 832 site.

Reproduction - The litter produced by the female $S$. dekayi from the HWY 832 site came earlier (by 20 days) than previous litters (13 August-20August) from Erie County noted by Gray and Lethaby (2008). The litter size $(n=20)$ was also the largest reported for an Erie County female $S$. dekayi, but within the range of 5-25 neonates for Pennsylvania populations (Hulse et al. 2001). Clausen (1936) reported that in most cases female neonates were larger than males, and this was true with the HWY 832 litter. The observed RCM of 0.441 is similar to that reported for $S$. d. texana (RCM 0.359 ) by Seigel et al. (1986).

Mortality and injuries - Gaul (2008) identified automobile traffic as the primary source of mortality for an urban North Carolina population of S. dekayi. Although this was not the case along the slope of the HWY 832 Bridge, five DOR S. dekayi were found on nearby trails and roadways (see above).

Although it is most likely that the 3 dead $S$. dekayi found beneath debris at the HWY 832 site were the result of a person stepping on them, it is also possible that some of this mortality could have been caused by White-tailed Deer (Odocoileus virginianus). In Pennsylvania, adult male deer average 140 pounds $(63.5 \mathrm{~kg})$ and females a little less (Fergus 2000). This is more than enough weight to crush a small snake under debris. On two oc-

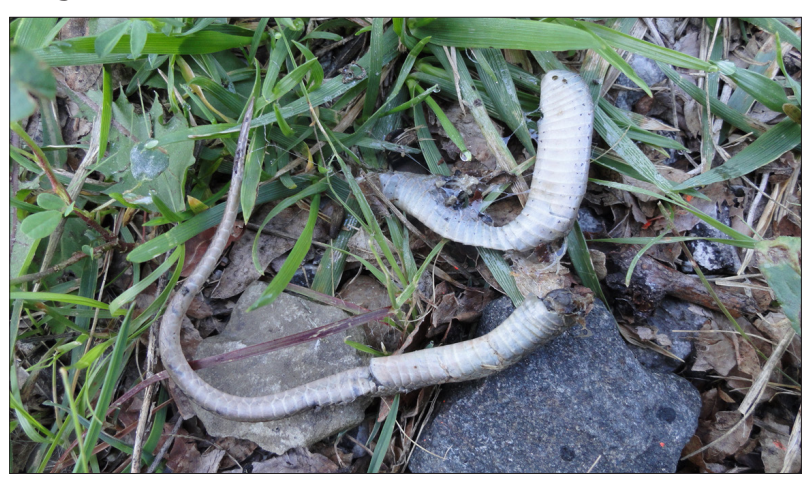

Figure 7. Remains of an adult female Storeria dekayi found on the trail at the base of the slope 20 August 2012. This female had produced a litter of twenty young 20 July 2012. 
casions deer were observed within $10 \mathrm{~m}$ of a debris station, and on numerous occasions deer tracks were seen on adjacent trails. It is foreseeable that deer traveling east from the swamp forest would encounter the HWY 832 Bridge, which acts as a barrier, and be forced to walk alongside it, thus increasing the likelihood of debris adjacent to the trail being stepped on. Milksnakes ( $L$. triangulum) have previously been reported to be a predator of S. dekayi (Ernst and Ernst 2003). The two observations of unmarked $S$. dekayi being disgorged by juvenile $L$. triangulum were made on 19 May 2012 and 7 September 2012, respectively, and are evidence that juvenile Milksnakes may be a significant predator of $S$. dekayi at this site. On 20 August 2012, a 105 mm tail-posterior and 45 $\mathrm{mm}$ midbody sections of a marked female were found on the trail below the slope (Figure 7). I was unable to determine the identity of the predator responsible for her death. There were slime trails from slugs on and adjacent to the remains which suggest that they may have been foraging on the carcass.

In addition to Milksnakes, other known predators of $S$. dekayi that occur at the site include: Northern Shorttailed Shrew (Blarina brevicauda) (Figure 8), Virginia Opossum (Didelphis virginiana), Raccoon (Procyon lotor), Domestic Cats (Felis catus), Striped Skunks (Mephitis mephitis), Common Gartersnake ( $T$. sirtalis), and Robins (Turdus migratorius). Nearly 20 years ago, approximately $1.3 \mathrm{~km}$ west of the HWY 832 Bridge, just north of the CSX RR tracks, I watched a Blue Jay, Cyanocitta cristata, attacking a S. dekayi. I attempted to get a better view of the interaction, but my approach scared the bird away, at which point I picked up and examined the snake, which did not appear to have any noticeable injuries.

Stub-tailed individuals represented $4 \%$ of the 166 S. dekayi observed. Although attempted predation may cause stubbed tails, frostbite (Ernst 2003) and incomplete shedding of the skin on the tail may cause a similar condition. During abnormal ecdysis, a constriction may form from unshed stratum corneum on the tail which may result in necrosis and loss of the tail tip. On 16 June 2012 a male S. dekayi was found at the HWY 832 site with retained stratum corneum on the dorsal surface of the tail. The causes of most of the stubbed tails at the site are unknown; however, that of a female found 7 June 2012, was extensive (Figure 9) and was more than likely the result of attempted predation. This snake was 305 $\mathrm{mm} \mathrm{SVL}$, with only $6 \mathrm{~mm}$ of the base of the tail remaining. Average tail length of 23 adult female $S$. dekayi at this site was $66 \mathrm{~mm}$; therefore it is reasonable to as-

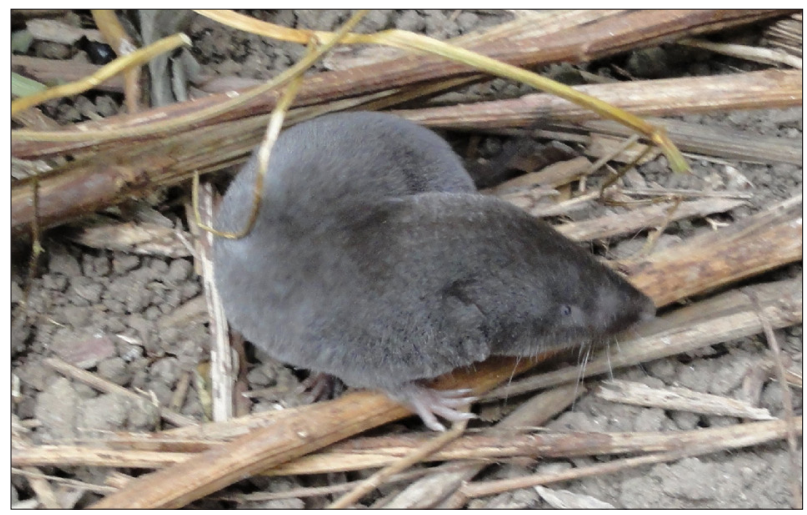

Figure 8. The Northern Short-tailed Shrew, Blarina brevicauda is a known predator of Storeria dekayi, and was found beneath several of the debris objects. sume that she lost approximately $91 \%$ of her tail. The injury was relatively recent, as it was still bleeding and not scabbed.

Prey - Catling and Freedman (1980a) observed that the distribution of $S$. dekayi corresponded well with areas of abundance of slugs and earthworms. This appeared to be the case at the HWY 832 site as well. My observations regarding the diet of $S$. dekayi were similar to those of Judd (1954) and Catling and Freedman $(1980 \mathrm{~b})$, with slugs being consumed more often than earthworms. Lumbricus rubellus is a European exotic earthworm usually found in surface litter or under debris (Reynolds 1977), and has been implicated in reducing plant diversity in hardwood forests that were previously earthworm-free (Hale et al. 2006).

All slugs (Arion and Deroceras) consumed by S. dekayi at the HWY 832 site were European exotics (Figure 10). The millipedes were likely consumed accidentally (Gray 2013a). Other potential prey at the site includes the slugs, $A$. subfuscus and $D$. laeve, and the earthworms: Allolobophora chlorotica, Amynthas sp., Aporrectodea sp., and $L$. terrestris. Competition for food resources between S. dekayi and Thamnophis sirtalis at the HWY 832 site is likely minimal, at least in adult snakes. When it comes to foraging, S. dekayi is reportedly more active during the early evening and at night (Ernst and Ernst 2003). Whereas $T$. sirtalis is more diurnal in its habits, although nocturnal foraging for anurans has been reported (Ernst and Ernst 2003). Additionally, S. dekayi at the HWY 832 site apparently feed more often on slugs than earthworms (Gray 2013b); although elsewhere, such as Kansas, earthworms seem to represent a more important component of the diet (Fitch 1999; Pisani 2009). Compared to $S$. dekayi, $T$. sirtalis is a more generalized predator, incorporating not only earthworms in their diet, but also amphibians, other snakes, small mammals, birds, and even carrion (Hulse et al. 2001; Gray 2002). Juvenile $T$. sirtalis, however, may consume earthworms almost exclusively (Fitch 1965), and were found to consume $L$. rubellus at the HWY 832 site (Figure 11 ).

Temperature - The lowest and highest BTs of S. dekayi observed by Ernst (2003) at two southeastern Pennsylvania sites were $3.0^{\circ}$ and $29.5^{\circ} \mathrm{C}$, respectively. A similar range of BTs $\left(2-27^{\circ} \mathrm{C}\right)$ were reported by Clarke (1958) for Kansas S. dekayi. The BT of $-0.2^{\circ} \mathrm{C}$ recorded for two males captured 29 April 2012 was the lowest recorded for this species (Subsequently, a BT of $-4.8^{\circ} \mathrm{C}$ was recorded for a juvenile male $S$. dekayi (Gray in press). All three snakes were stiff and torpid when initially picked

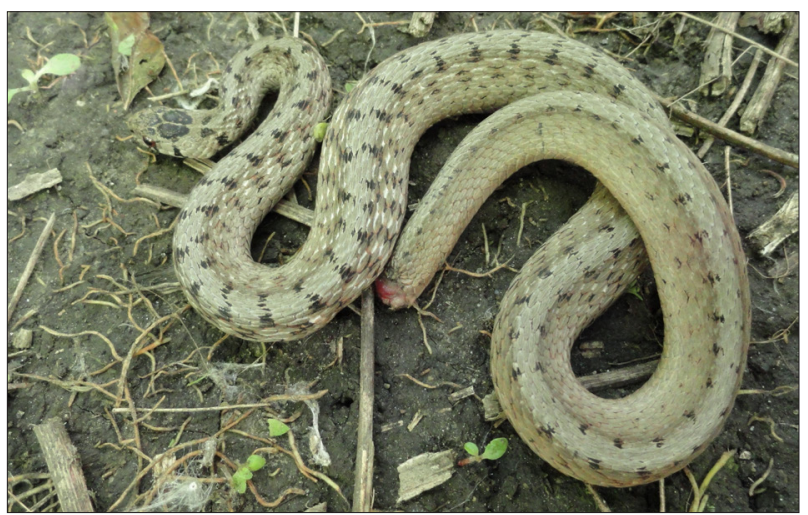

Figure 9. Stub-tailed adult female Storeria dekayi $(305 \mathrm{~mm}$ SVL) found 7 June 2012. The injury was likely a result of attempted predation. 
up. Only after several seconds in the hand did they move, and even then, their movements appeared labored and limited. After approximately a minute of handling, a clear liquid and uric acid crystals were excreted from the cloaca. A female ( $262 \mathrm{~mm} \mathrm{SVL}$ ) found under a board $2.4 \mathrm{~m}$ from the aforementioned two male snakes had a BT of $0.6^{\circ} \mathrm{C}$, and responded in much the same way as the males. Air temperature overnight (28-29 April) prior to the observations had dropped to $-1.1^{\circ} \mathrm{C}$; at the time of the observation there was frost on the ground and AT was $3.5^{\circ} \mathrm{C}$. Two of the snakes (a male and female) captured on 29 April were recaptured 7-32 days afterwards, and thus survived the exposure to potentially lethal temperatures $\left(-0.2\right.$ and $\left.0.6^{\circ} \mathrm{C}\right)$. The highest recorded BT of any S. dekayi at the HWY 832 site was $30.6^{\circ} \mathrm{C}$, and was higher than previously reported for the species (Clarke 1958; Ernst 2003). Noble and Clausen (1936) reported the maximum temperature tolerance of S. dekayi to be $39-44^{\circ} \mathrm{C}$. Differences in the techniques used in obtaining BTs, for instance using quick-reading cloacal thermometers (e. g. Clarke 1958; Ernst 2003), and the employment of a noncontact infrared thermometer in the present study may confound comparisons between studies. However, Hare et al. (2007) found that if appropriately oriented when aiming at small reptiles (along the body axis), hand-held IR thermometers record values for skin temperatures that can substitute for measurements taken with a cloacal thermocouple. Nearly all BTs $(99.5 \%)$ obtained from $S$. dekayi at the HWY 832 site were from individuals found under some sort of cover. Therefore, the BTs recorded in the present study more than likely represent temperatures passively experienced by the snakes, and not necessarily temperatures chosen by them. This is especially true of snakes found during morning surveys.

Movements and site fidelity - Storeria dekayi has been reported as being capable of traveling relatively long distances ( $>1 \mathrm{~km}$ ) (Noble and Clausen 1936); however, most movements are much shorter. Freedman and Catling (1979) reported minimum distance traveled by male and female S. dekayi in Ontario, Canada, to average 197 $\mathrm{m}$ and $59 \mathrm{~m}$, respectively. Pisani (2009) noted that average distances traveled were $48 \mathrm{~m}$ for males and $55 \mathrm{~m}$ for females, which were similar to distances traveled by S. dekayi at the HWY 832 site. Utilizing movement data from two southeastern Pennsylvania populations, Ernst (2003), estimated average home range diameters to be $39 \mathrm{~m}$ for males, and $47 \mathrm{~m}$ for females. Furthermore, Ernst noted that most recaptures of $S$. dekayi were made less than $40 \mathrm{~m}$ from the previous capture site, and this was

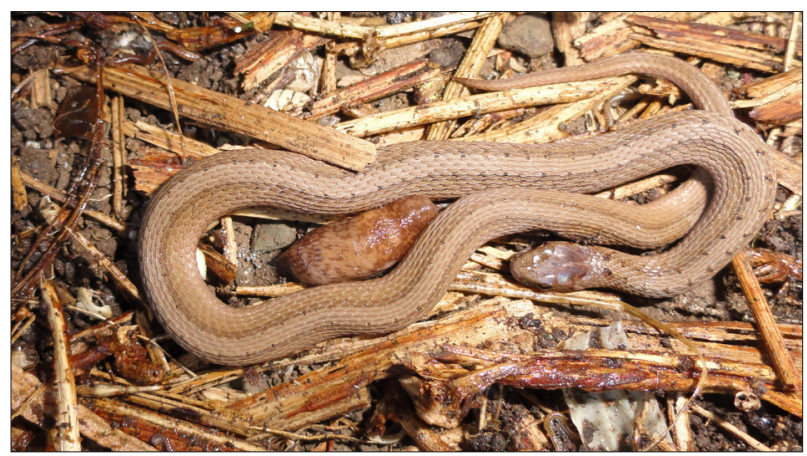

Figure 10. The Milky Slug, Deroceras reticulatum (between coiled body of a Storeria dekayi) was common along the Hwy 832 Bridge, and was consumed by S. dekayi at the site. The slug in the photograph is larger than those that were consumed. the case at the HWY 832 site as well. The total distances traveled by $S$. dekayi at the Hwy 832 site were somewhat lower than the maximum distances observed by Freedman and Catling (1979) of 517 m; or Ernst (2003) of 670 $\mathrm{m}$, but were similar to Pisani (2009), who reported 150 $\mathrm{m}$. At the HWY 832 site total possible distance traveled was constrained by limited habitat and availability of debris. Any snakes moving beyond the outermost debris objects would likely not have been sampled. On several occasions, I searched debris piles located 74 - $164 \mathrm{~m}$ to the west of the bridge, without finding any marked snakes.

Ernst (2003) noted a high incidence of site-fidelity (mean return rates of $63-67 \%$ ) at hibernacula at two Lancaster County, Pennsylvania sites. Pisani (2009) at a Kansas site found that 7 of 19 S. dekayi with multiple recaptures were found at the same shelter they had used previously. One female, for instance used the same piece of tin five times. Clausen (1936) observed site-fidelity by three gravid S. dekayi in New York. I previously reported site-fidelity by three $S$. dekayi during ecdysis from the HWY 832 site (Gray 2008). The additional observations of site-fidelity during ecdysis noted above illustrate the importance of conserving a mosaic of habitat types for use by snakes not only for ecdysis, but also for thermoregulation, acquisition and digestion of food, and hibernation.

Seasonal activity - Hulse et al. (2001) noted a unimodal activity pattern in Pennsylvania S. dekayi females, but a bimodal pattern in males. Data presented in Fitch (1999) for Kansas S. dekayi is also suggestive of a bimodal activity period, with a peak in spring (April) and a second peak in the autumn (September and October). Gaul (2008) observed a bimodal activity period in a North Carolina population of $S$. dekayi, and noted that the peak of surface activity in November was apparently stimulated by rainfall events. Meshaka et al. (2008) observed a unimodal activity pattern in S. dekayi from Portage County, Ohio. The bimodal activity period observed at the HWY 832 site, with peaks of both sexes in April and August, was different from Hulse et al. (2001) and Meshaka et al. (2008). Furthermore, it differs from that previously reported for the Central Lowland Province of Erie County, Pennsylvania, where the major peak occurred in June, followed by a second, minor peak in September (Gray 2011) (Figure 12). Data from my 2011 paper was pooled from multiple years (1995-2009) and from two sites and may explain the differences between surveys. The comparisons are also confounded due to differences in environmental factors. The winter of 2011

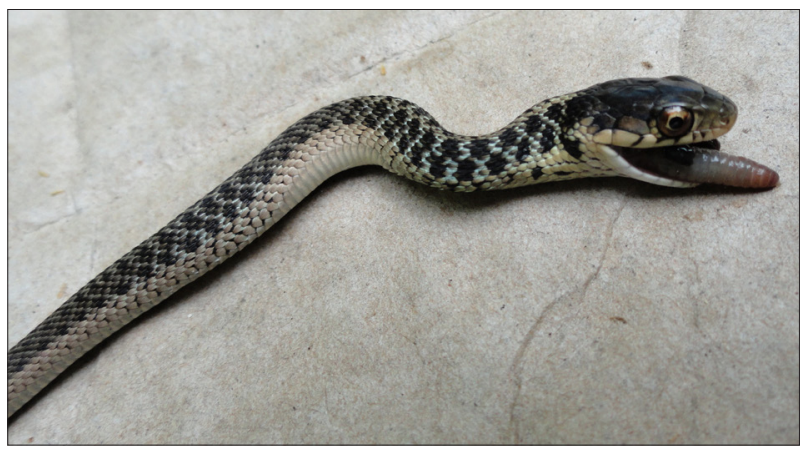

Figure 11. Juvenile Thamnophis sirtalis like the one pictured here consuming a Lumbricus rubellus at the HWY 832 site, may potentially compete with Storeria dekayi for food resources, although this has not yet been demonstrated. 
- 2012 was very mild, with an unusually dry summer during 2012. Pisani (2009) noted that apparent seasonal bimodality of activity of snakes from a site in Kansas could be an artifact of shelter sampling. Such a situation is possible in the current survey and should be taken into account when interpreting these data. The high number of observations in April was likely the result of snakes aggregating near their hibernaculum. The decrease in observations during June and July may have been due to increased temperatures and lack of precipitation, resulting in a decrease in the activity of prey (e.g. slugs and earthworms) and snakes. Average air temperature (AT) at the HWY 832 site during June $\left(24^{\circ} \mathrm{C}\right)$ and July $\left(25.0^{\circ} \mathrm{C}\right) 2012$ were above the average normal temperature for the region by $4.5^{\circ} \mathrm{C}$ and $2.9^{\circ} \mathrm{C}$, respectively (NOAA. 2012). On 15 July 2012 the temperature beneath some of the debris stations was as high as $40.4^{\circ} \mathrm{C}$. This temperature is within the maximum temperature tolerance of S. dekayi (39-44 C) (Noble and Clausen 1936). Precipitation at the site was also below normal; on 2 July 2012 it was nearly $101.6 \mathrm{~mm}$ below average (Gray 2012). In response to unfavorable dry conditions on the slope, snakes (and prey) may have moved to more humid areas in the adjacent palustrine forest, or within clumps of vegetation (Noble and Clausen 1936), which were not searched. June and July had relatively high amounts of effort devoted to them, with 11 and 9.8 hrs, respectively. Thus the decrease in observations cannot be attributed to lack of search effort. The peak in observations during August was in part due to births occurring during the end of July and into August. Of 106 observations of $S$. dekayi between 16 August and 22 October, nearly eightysix percent $(n=91)$ were of juveniles, most of which were young of the year snakes. The apparent increase in captures of adult females during the autumn months may have been a result of postpartum foraging (Hulse et al. 2001). The earliest and latest dates of observation, 21 March and 22 October, respectively were similar to those reported for Pennsylvania in general (Hulse et al. 2001), and Erie County in particular (Gray and Lethaby 2008).

Overall, S. dekayi was the most frequently observed ( $n=308$ ) snake at the HWY 832 site, followed by $T$. sirtalis ( $n=246)$, and L. triangulum $(n=20)$. However, during the period 16 June - 15 August $T$. sirtalis was the most frequently observed (Table 6); possibly a result of its more generalized diet and its tolerance of higher temperatures than $S$. dekayi.

Storeria dekayi are known for their ability to thrive in urban and disturbed habitats, and can also successful-

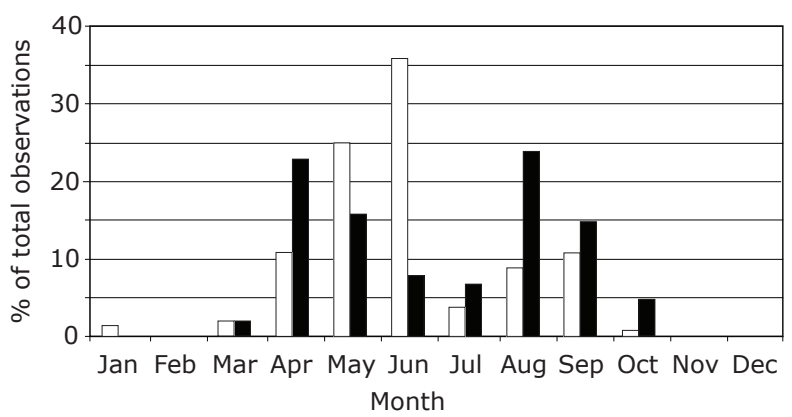

Figure 12. A comparison of the seasonal activity of Storeria dekayi from two studies. The total number of observations of $S$. dekayi from the Central Lowland Province of Erie County, Pennsylvania reported in Gray (2011) (white bars) was 243; while observations for the current study of $S$. dekayi (black bars) from the HWY 832 site were 308. The percentage of the total observations for each month is reported in the graph. ly colonize new areas when introduced (Lee 2005; Cook 2008). Despite this resilience, population declines and extirpations of $S$. dekayi have been reported (Mitchell 1994; Ernst 2003; Murphy 2010). Although S. dekayi is relatively common in Erie County (Gray and Lethaby 2008), at some sites, such as Asbury Woods, it is uncommon (Gray 2006). While S. dekayi is not yet rare or threatened in Pennsylvania, there is still a need for information regarding some aspects of its natural history and ecology, such as population sizes and density, and habitat utilization within the commonwealth. The baseline data presented herein augments our understanding of the natural history and ecology of S. dekayi in Pennsylvania, and it is hoped that it will encourage further investigations that would allow for the development and implementation of conservation and management plans that could protect this currently abundant species should it be necessary.

\section{ACKNOWLEDGMENTS}

I wish to express my gratitude to James Harding, Walter Meshaka, Jr., and George Pisani for comments and suggestions that helped refine the manuscript.

\section{LITERATURE CITED}

Burroughs, W. S. 1987. The Western Lands. Viking Penguin Inc., New York, NY.

Catling, P. M. and B. Freedman. 1980a. Variation and abundance of four sympatric species of snakes at Amherstburg, Ontario. Can. Field Nat. 94:19-27.

Catling, P. M. and B. Freedman. 1980b. Food and feeding behavior of sympatric snakes at Amherstburg, Ontario. Can. Field Nat. 94:28-33.

Caughley, G. 1977. Analysis of Vertebrate Populations. John Wiley \& Sons Ltd, London, UK.

Clarke, R. F. 1958. An ecological study of reptiles and amphibians in Osage County, Kansas. Emporia St. Res. Stud. 7: 1-52.

Clausen, H. J. 1936. Observations of the brown snake, Storeria dekayi (Holbrook) with especial reference to the habits and birth of the young. Copeia 1936:98102.

Conant, R. 1938. The reptiles of Ohio. Amer. Midl. Nat. $20: 1-200$.

Cook, R. P. 2008. Potential and limitations of herpetofaunal restoration in an urban landscape. Pp 465-478. In: Mitchell, J. C., R. E. Jung Brown, and B. Bartholomew (eds.). Urban Herpetology. Herpetological Conservation 3. Society for the Study of Amphibians and Reptiles.

Delury, D. B. 1958. The estimation of population size by a marking and recapture procedure. J. Fish. Res. Bd. Canada. 15:19-25.

Dodd, C. K. 1987. Status, Conservation, and Management. Pp 478-513. In: Seigel, R. A., J. T. Collins, and S. S. Novak. Snakes: Ecology and Evolutionary Biology. Macmillan Publishing Company, New York, NY.

Dorcas, M. E. and J. D. Willson. 2009. Innovative methods for studies of snake ecology and conservation. Pp. 5-37. In: Mullin, S. J. and R. A. Seigel (eds.). Snakes: Ecology and Conservation. Comstock Publishing Associates, Ithaca, NY.

Ernst, C. H. 2003. Ecological parameters of the Northern Brown Snake, Storeria dekayi. Herpetol. Bull. $86: 10-18$.

Ernst, C. H. and R. W. Barbour. 1989. Snakes of Eastern North America. George Mason University Press, Fairfax, VA. 
Ernst, C. H. and E. M. Ernst. 2003. Snakes of the United States and Canada. Smithsonian Press. Washington, DC.

Fergus, C. 2000. Wildlife of Pennsylvania and the Northeast. Stackpole Books, Mechanicsburg, PA. 438 pp.

Fitch, H. S. 1965. An ecological study of the garter snake, Thamnophis sirtalis. Univ. Kansas Publ. Mus. Nat. Hist. 15:493-564.

Fitch, H. S. 1999. A Kansas Snake Community: Composition and changes over 50 years. Krieger Publishing Co., Malabar, FL.

Freedman, W. and P. M. Catling. 1978. Population size and structure of four sympatric species of snakes at Amherstburg, Ontario. Can. Field Nat. 92:167-173.

Freedman, W. and P. M. Catling. 1979. Movements of sympatric species of snakes at Amherstburg, Ontario. Can. Field Nat. 93:399-404.

Gaul, R. W. 2008. Ecological observations of the Northern Brownsnake (Storeria dekayi) in an urban environment in North Carolina, USA. Pp. 361-363. In: Mitchell, J. C., R. E. Jung Brown, and B. Bartholomew (eds.). Urban Herpetology. Herpetological Conservation 3. Society for the Study of Amphibians and Reptiles.

Gray, B. 2002. Natural history notes. Thamnophis sirtalis sirtalis (Eastern Garter Snake). Diet. Herpetol. Rev. 33(2): 142-143.

Gray, B. S. 2006. The reptiles and amphibians of the Asbury Woods Greenway, Erie County, Pennsylvania. Bull. Maryland Herpetol. Soc. 42(2):115-126.

Gray, B. S. 2007. The herpetofauna of a national superfund site in Erie, Pennsylvania. Bull. Maryland Herpetol. Soc. 43(3):129-133.

Gray, B. S. 2008. A note on site fidelity for ecdysis in the Northern Brown Snake, Storeria dekayi dekayi. Bull. Chicago Herpetol. Soc. 43(3):39-41.

Gray, B. S. 2009. Recent observations of the herpetofauna of a former National Superfund Site in Erie, Pennsylvania. J. Kansas Herpetol. 31:9-11

Gray, B. S. 2011. Seasonal activity and natural history observations of five snake species from the Central Lowland Province of Erie County, Pennsylvania. J. Kansas Herpetol. 38:14-21.

Gray, B. S. 2012. A note on the diet of common garter snakes, Thamnophis sirtalis, in Pennsylvania. Bull. Chicago Herpetol. Soc. 47(8): 97-98.

Gray, B. S. 2013a. Natural history notes. Storeria dekayi (Dekay's Brownsnake). Diet. Herpetol. Rev. 44(3):527.

Gray, B. S. 2013b. The relative importance of slugs and earthworms in the diet of Dekay's Brownsnake, Storeria dekayi, from northwestern Pennsylvania. Bull. Chicago Herpetol. Soc. 48(12):157-165.

Gray, B. S. in press. Natural history notes. Storeria dekayi (Dekay's Brownsnake). Cold-tolerance. Herpetol. Rev.

Gray, B. S. and M. Lethaby. 2008. The amphibians and reptiles of Erie County, Pennsylvania. Bull. Maryland Herpetol. Soc. 44(2):49-69

Gregory, P. T., J. M. Macartney, and K. W. Larsen. 1987. Spatial Patterns and Movements. Pp 478-513. In: Seigel, R. A., J. T. Collins, and S. S. Novak. Snakes: Ecology and Evolutionary Biology. Macmillan Publishing Company, New York, NY.

Hale, C. M., L. E. Frelich, and P. B. Reich. 2006. Changes in cold-temperate hardwood forest understory plant communities in response to invasion by European earthworms. Ecology 87(7):1637-1649.

Hare, J. R., E. Whitworth, and A. Cree. 2007. Correct orientation of a hand-held infrared thermometer is important for accurate measurement of body temperatures in small lizards and tuatara. Herpetol. Rev. 38(3):311-315.

Hecnar, S. J., and D. R. Hecnar. 2011. Microhabitat selection of woody debris by Dekay's Brownsnake (Storeria dekayi) in a dune habitat in Ontario, Canada. J. Herpetol. 45(4):478-483.

Hulse, A. C., C. J. McCoy and E. J. Censky. 2001. Amphibians and Reptiles of Pennsylvania and the Northeast. Comstock Publishing Associates, Ithaca, New York.

Judd, W. W. 1954. Observations on the food of the little brown Snake, Storeria dekayi, at London, Ontario. Copeia 1954(1):62-64.

King, R. B. 1997. Variation in brown snake (Storeria dekayi) morphology and scalation: Sex, family, and microgeographic differences. J. Herpetol. 31(3):335-346.

Klemens, M. W. 1993. Amphibians and reptiles of Connecticut and adjacent regions. State Geological and Natural History Survey of Connecticut. Bull. 112.

Lazell, J. D. Jr. 1976. This Broken Archipelago: Cape Cod and the Islands Amphibians and Reptiles. Quadrangle/The New York Times Book Co., New York, NY.

Lee, D. S. 2005. Reptiles and amphibians introduced to the Bahamas; a potential conservation crisis. Bahamas Journal of Science 12:2-6.

Maret, T. J. 2010. The amphibians and reptiles: Introduction. Pp 26-29. In: Steele, M. A., M. C. Brittingham, T. J. Maret, and J. F. Merritt. (eds.). Terrestrial Vertebrates of Pennsylvania: A Complete Guide to Species of Conservation Concern. The John Hopkins University Press, Baltimore, MD.

McDiarmid, R. W. 2012. Reptile diversity and natural history: An overview. Pp 7-23. In: McDiarmid, R. W., M. S. Foster, C. Guyer, J. W. Gibbons, and N. Chernoff (Eds.). 2012. Reptile Biodiversity: Standard Methods for Inventory and Monitoring. University of California Press, Berkeley, CA.

McDiarmid, R. W., M. S. Foster, C. Guyer, J. W. Gibbons, and N. Chernoff (eds.). 2012. Reptile Biodiversity: Standard Methods for Inventory and Monitoring. University of California Press, Berkeley, CA.

Meshaka, W. E., Jr. 2010. Field observations of eleven species of snakes during twenty-six years at Hawk Mountain Sanctuary, Pennsylvania. J. Kansas Herpetol. 36:17-20.

Meshaka, W. E., Jr., S. D. Marshall, and T. J. Guiher. 2008. Seasonal activity and reproductive characteristics of an oldfield-grassland snake assemblage: Implications for land management. Herpetol. Bull. 105:35-40.

Minton, Jr., S. A. 2001. Amphibians and Reptiles of Indiana. Revised 2 nd edition. Indiana Academy of Science, Indianapolis, Indiana.

Mitchell, J. C. 1994. The Reptiles of Virginia. Smithsonian Institution Press, Washington, DC.

Murphy, J. C. 2010. Secrets of the Snake Charmer: Snakes in the 21st Century. iUniverse Inc., New York, NY.

NOAA. 2012. http://www.erh.noaa.gov/cle/climate/eri/ normals/erinrtjul.html. Accessed 27 June 2012.

Noble, G. K., and H. J. Clausen 1936. The aggregation behavior of Storeria dekayi and other snakes with 
especial reference to the sense organs involved. Ecol. Monogr. 6:269-316.

Parker, W. S., and M. V. Plummer. 1987. Population ecology. Pp. 253-301 In Seigel, R.A., J. T. Collins, and S. S. Novak. Snakes: Ecology and Evolutionary Biology. MacMillan Publishing Co., New York, NY.

Pisani, G. R. 2009. Virginia valeriae and Storeria dekayi in a northeastern Kansas grassland community: ecology and conservation implications. J. Kansas Herpetol. 32:20-36.

Reynolds 1977. The Earthworms (Lumbricidae and Sparganophilidae) of Ontario. Life Sci. Misc. Pub., Roy. Ontario Mus. xi + 141pp.

Ricker, W. E. 1975. Computation and interpretation of biological statistics of fish populations. Fisheries Research Board of Canada, Bull. 191.

Rossman, D. A., N. B. Ford, and R. A. Seigel. 1996. The Garter Snakes: Evolution and Ecology. University of Oklahoma Press, Norman, OK.

Runyon, R. P., A. Haber, D. J. Pittenger, and K. A. Coleman. 1996. Fundamentals of Behavioral Statistics. McGraw Hill Co., New York, NY.

Schneider, J. C. 1998. Lake fish population estimates by mark-and-recapture methods. Chapter 8 in: J. C. Schneider (ed.). 2000. Manual of fisheries survey methods II: With periodic updates. Michigan Department of Natural Resources, Fisheries Special Report 25, Ann Arbor.
Seber, G. A. F. 1973. The Estimation of Animal Abundance and Related Parameters. Charles Griffin \& Co., London.

Seigel, R. A., H. S. Fitch, and N. B. Ford. 1986. Variations in relative clutch mass in snakes among and within species. Herpetologica 42(2):179-185.

Shine, R. 1993. Sexual dimorphism in snakes. Pp. 4986. In: R. A. Seigel and J. T. Collins (eds.). Snakes: Ecology and Behavior. McGraw-Hill Inc., New York, NY.

Shine, R., and X. Bonnet. 2009. Reproductive Biology, Population Viability, and Options for Field Management. Pp. 172-200. In: Mullin, S. J. and R. A. Seigel (eds.). Snakes: Ecology and Conservation. Comstock Publishing Associates, Ithaca, NY.

Shine, R., and D. Crews. 1988. Why male garter snakes have small heads: The evolution and endocrine control of sexual dimorphism. Evolution 42:1105-1110.

Vitt, L. J., and J. P. Caldwell. 2009. Herpetology: An Introductory Biology of Amphibians and Reptiles. Third edition. Academic Press, Boston, MA.

Willson, J. D. and M. E. Dorcas. 2004. Aspects of the ecology of small fossorial snakes in the western Piedmont of North Carolina. Southeastern Nat. 3(1):1-12.

Winne, C. T., J. D. Willson, K. M. Andrews and R. N. Reed. 2006. Efficacy of marking snakes with disposable medical cautery units. Herpetol. Rev. 37(1):52-54. 